\title{
Eye Regeneration and Healing
}

\author{
Carmen Álvarez* \\ Ophthalmologist, Specialist in ocular plasty and ocular surface, Venezuela
}

Submission: March 29, 2019; Published: April 18, 2019

*Corresponding author: Carmen Álvarez, Ophthalmologist, Specialist inocular plasty and ocular surface, Venezuela

Keywords: Tumor; Ulcers; Epithelial defects; Cornea; Conjunctiva; Amniotic membrane

\section{With Amniotic Membrane}

If a person has suffered some tumor, ulcers, epithelial defects of the cornea and the conjunctiva, the treatment with Amniotic Membrane (MA) provides very satisfactory results to achieve the healing and reconstruction of the ocular surface in the short and long term. The Ophthalmologist Carmen Álvarez, specialist in oculoplasty and ocular surface; affirms that it is possible to opt for the use of the amniotic membrane, a medical-surgical procedure that is also used to increase the chances of success in some corneal surgeries, when there are cases with problems of tissue regeneration or scarring in the postoperative period. The specialist mentions that the amniotic membrane is used since the 40s in ophthalmology and is the inner most layer of the placenta, which is obtained in deliveries performed by elective cesarean sections. Prior to obtaining the placenta -Indica Álvarez- the written authorization of the mother is needed and the same protocol for the donation of other tissues is made. "It is an essential requirement to avoid possible transmission of infectious diseases in the recipient and other complications," he warns.

\section{MA Deflates and Heals}

The Amniotic Membrane (MA) explains Álvarez- is a resistant tissue, transparent, thin and rich in collagen that lines the placenta, in the period of fetal development, very similar to the skin. It is formed by three layers: epithelial, basal membrane and stromal matrix. "The basement membrane facilitates the migration of the epithelial cells responsible for the differentiation and proliferation of corneal surface cells and inhibits their death," says the specialist. Amnio is of fetal origin and becomes the inner layer. Its outer surface is composed of connective tissue and epi thelial cells. "Amnio alone does not provide stem cells, but allows proper reproduction and migration of epithelial cells, meaning that the amniotic membrane acts to promote reepithelialization of the cornea and releases substances with great anti-inflammatory power, promotes healing, reduces the production of fibrosis and the formation of new vessels on the ocular surface, "explains the ophthalmologist.

\section{How does it work?}

Álvarez mentions that the use of the amniotic membrane can cure in two ways:

a) As a graft, that is, placing the basement membrane upwards to produce a growth of the epithelial tissue above the MA, restoring the ocular surface.

b) By coating placing the basement membrane down to reduce the inflammatory process, favor re-epithelialization and decrease the healing process under the membrane.

The ophthalmologist explains that it is currently used successfully in ocular surface surgeries.

a) Corneal reconstruction: recurrent corneal erosions, corneal ulcers, perforations, bullous keratopathy and persistent epithelial defects.

b) Conjunctival lesions: pterygium, epithelial tumors, damaged blisters in glaucoma surgery.

c) Healing ocular lesions: Symbéfaron, deficiency of stem cells, scleromalacia, reconstruction of the cul-de-sac, band keratopathy, temporary coating and in the treatment of chemical ocular burns. 


\section{Your next submission with Juniper Publishers will reach you the below assets}

- Quality Editorial service

- Swift Peer Review

- Reprints availability

- E-prints Service

- Manuscript Podcast for convenient understanding

- Global attainment for your research

- Manuscript accessibility in different formats

( Pdf, E-pub, Full Text, Audio)

- Unceasing customer service

Track the below URL for one-step submission https://juniperpublishers.com/online-submission.php 